\title{
List of plates
}

All plates appear between pages 97 and 108

1a Composite shot of Madeline, La Chute de la maison Usher (1928) courtesy of All Day Entertainment

1b A montage of stills of the Russian actress Alla Nazimowa in Epstein's Bonjour cinéma (1921)

2 Shivering curtain, La Chute de la maison Usher (1928) @ La Cinémathèque française

3 Funeral procession with its hand-held 'heaving' shot, La Chute de la maison Usher (1928) (C) La Cinémathèque française

4 Jean (Léon Mathot) the melancholy dockworker, Cour fidèle (1923) (C) Pathé Archives and (C) La Cinémathèque française

5 Marie (Gina Manès) and Petit-Paul (Edmond van Daële) on the first merry-go-round sequence, Cœur fidèle (1923) (C) Pathé Archives and (C) La Cinémathèque française

6 Third shot to last in the epilogue, Cour fidèle (1923) (C) Pathé Archives and (C) La Cinémathèque française

7 Still from the vivisection scene of the inoculation of rabies in a rabbit, Pasteur (1922) courtesy of Institut National de l'Audiovisuel.

8a Peasant holding boy bit by a rabid dog, Pasteur (1922) courtesy of Institut National de l'Audiovisuel

8b Counter-shot of swooned boy's face, Pasteur (1922) courtesy of Institut National de l'Audiovisuel

8c Boy's crying face in Pasteur's imagination, Pasteur (1922) courtesy of Institut National de l'Audiovisuel

9 Two women dancing together, with a superimpression of Anna, Le Lion des Mogols (1924) (C) La Cinémathèque française

10 Protagonist getting in his car, shot through a vegetable cart, La Glace à trois faces (1927) (C) La Cinémathèque française 
11 Protagonist in his automobile glass closet, La Glace à trois faces (1927) (C) La Cinémathèque française

12 Androgynous Jean (Nino Constantini), Six et demi onze (1927) C La Cinémathèque française

13 Jean shoots at the mirror, holding a camera, before killing himself, Six et demi onze (1927) (C) La Cinémathèque française

14 Photo strip from Jean's camera, dangling in front of Jérôme's eyes, Six et demi onze (1927) (C) La Cinémathèque française

15 Reflections on the Hispano-Suiza car, L'Homme à l'Hispano (1932) (C) DR / Collection Cinémathèque française

16 Pierre Batcheff in his mother's arms, Le Double amour (1925) (C) La Cinémathèque française

17a Composite shot of Pierre Batcheff, the singing 'Apache', the lute, and feather fan, Le Double amour (1925) (C) La Cinémathèque française

$17 \mathrm{~b}$ With three men circling each other, Le Double amour (1925) (C) La Cinémathèque française

18a Ambroise, Finis Terra (1929) (C) Gaumont Pathé Archives and (C) La Cinémathèque française

18b Jean-Marie, Finis Terrce (1929) (C) Gaumont Pathé Archives and (C) La Cinémathèque française

19 Broken bottle with two small daisies, Finis Terrce (1929) (C) Gaumont Pathé Archives and (C) La Cinémathèque française

20 Ambroise's injured thumb, Finis Terre (1929) (C) Gaumont Pathé Archives and (C) La Cinémathèque française

21 Example of intertitle verse, Morv'ran (1930) (C) La Cinémathèque française

22 A ghostly shirt, or the wind embodied, Morv'ran (1930) (C) La Cinémathèque française

23 Lighthouse keeper behind the lens, Morv'ran (1930) C) La Cinémathèque française

24a Soizic showing her shy beauty to Rémy, L'Or des mers (1932) (C) La Cinémathèque française

24b Soizic trapped in quicksand, L’Or des mers (1932) C La Cinémathèque française

25 'Zip-line' shot of the quarry, found in both La Bourgogne (1936) and Les Bâtisseurs (1938) C Ciné-Archives - fonds audiovisuel du PCF

26 Two masons working on a cathedral, Les Bâtisseurs (1938) C CinéArchives - fonds audiovisuel du PCF

27 Animated cartoon depicting Le Corbusier's utopian social housing, Les Bâtisseurs (1938) C Ciné-Archives - fonds audiovisuel du PCF 